\title{
Progesterone secretion during pregnancy in sheep with an autotransplanted adrenal and an autotransplanted ovary
}

\author{
F. A. Harrison and R. B. Heap \\ A.R.C. Institute of Animal Physiology, Babraham, Cambridge CB2 4AT, U.K.
}

\begin{abstract}
Summary. Secretion rates by the major sites of progesterone synthesis were measured during pregnancy in 3 ewes with single fetuses after autotransplantation of the left adrenal and the left ovary (containing the corpus luteum) to the neck. The total production of progesterone measured by tracer kinetics increased from $12 \cdot 1 \pm 2 \cdot 0$ (s.e.m.) to $31 \cdot 3 \pm 2 \cdot 4 \mu \mathrm{g} / \mathrm{min}$ between $66-103$ and 133-145 days p.c. Ovarian and adrenal secretion rates measured directly at the same times decreased from $5 \cdot 2 \pm 0.9$ to $2 \cdot 1 \pm 0.9 \mu \mathrm{g} / \mathrm{min}$ (ovary), or remained unchanged, about $0.03 \mu \mathrm{g} / \mathrm{min}$ (adrenal). The difference between the total production of progesterone and ovarian and adrenal secretion showed that the contribution from other endocrine tissues (presumably the placenta) increased from $6.8 \pm 1.5$ to $29.2 \pm 4.1 \mu \mathrm{g} / \mathrm{min}(P<0.001)$ during this period.
\end{abstract}

\section{Introduction}

In the sheep ovariectomy performed before Day 50 post coitum (p.c.) causes abortion or resorption of the conceptus (Casida \& Warwick, 1945; Denamur \& Martinet, 1955). The likelihood of the pregnancy being maintained after ovariectomy increases later in gestation, presumably due to the increasing ability of the placenta to secrete progesterone. The following experiment was performed to determine the relative contributions of the ovary, the adrenal and the other sites of synthesis to the total production rate of progesterone at different times of gestation. A preliminary report has has been published (Harrison \& Heap, 1968).

\section{Materials and Methods}

The studies were carried out in 5 conscious trained sheep (Merino $\times$ Welsh Mountain) in which an adrenal and an ovary had been autotransplanted to the neck (Text-fig. 1) so that determinations of ovarian and adrenal progesterone secretion rates could be made by direct measurement. The left adrenal was transplanted to a left carotid artery-jugular vein skin loop (McDonald, Goding \& Wright, 1958) and the right adrenal was removed 1 week later. After normal pregnancies, the right ovary was removed and the sheep mated again. The left ovary was then transplanted to a right carotid artery-jugular vein skin loop (Goding, McCracken \& Baird, 1967) 31 days (Edwina, twins), 33 days (Flossie, singleton), 34 days (Godiva, singleton), 35 days (Florence, twins) and 41 days (Frances, singleton) after mating. On the day of operation, and for up to 5 days afterwards, decreasing doses (from 15 to $3 \mathrm{mg} /$ day) of progesterone in oil (Intervet Ltd, Bar Hill, Cambridge) were given by intramuscular injection.

Blood flow was determined by collection of timed samples from catheters inserted into the left jugular (adrenal) and the right jugular (ovary) vein by the method described by Harrison \& Paterson (1965); the estimates included flow through the skin surrounding the major vessels and the transplants. The product of blood flow and blood progesterone concentration was calculated to obtain the progesterone secretion rate by the ovary and adrenal. Blood progesterone concentration, the metabolic clearance rate and the total production rate of progesterone measured in blood were determined by the techniques described by Bedford, Harrison \& Heap (1972). The concentration of 
progesterone in blood was determined by a competitive protein-binding technique for which the recovery of $\left[{ }^{3} \mathrm{H}\right]$ progesterone added to whole blood was $95 \%$, the assay blank value was $0.33 \pm 0.04$ (s.e.m.) $\mathrm{ng} / \mathrm{ml}$ (18 determinations) for blood taken from an ovariectomized sheep (which was also unilaterally adrenalectomized), and after the addition of $1 \cdot 0,2 \cdot 0$ and $4.0 \mathrm{ng}$ progesterone the amount determined was $1 \cdot 3 \pm 0.2,2.0 \pm 0.4$ and $3.7 \pm 0.6$ (s.e.m.) $\mathrm{ng} / \mathrm{ml}$ (6 determinations at each concentration).

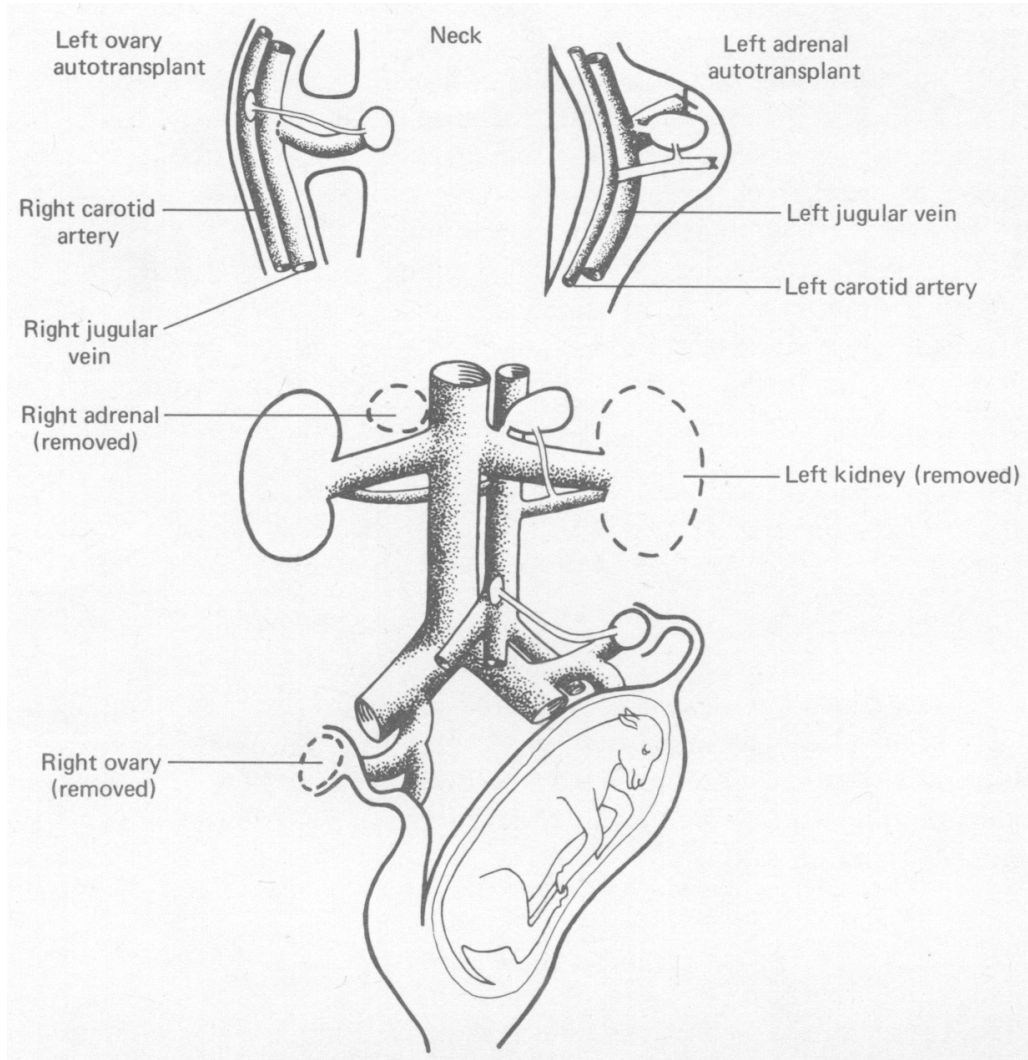

Text-fig. 1. Diagram of the combined adrenal and ovary transplantation in the pregnant sheep.

\section{Results}

The 2 ewes with twin pregnancies and bearing 2 corpora lutea in the transplanted ovary aborted at 48 (Florence) and 55 (Edwina) days of gestation, i.e. 13 and 24 days respectively after the ovarian transplantation. The 3 ewes with single fetuses and only one corpus luteum in the transplanted ovary maintained apparently normal pregnancies and delivered live female lambs after 146 (Frances) and 148 (Godiva, Flossie) days of gestation. Normal term for 24 singleton pregnancies in 16 multiparous Merino-cross ewes with ovaries in situ was $147 \pm 0.6$ (s.e.m.) days. The lamb body weights at birth (Frances, $3.5 \mathrm{~kg}$; Flossie, $4.5 \mathrm{~kg}$; Godiva, $5.0 \mathrm{~kg}$ ) were within the range for 22 single lambs (mean $4 \cdot 1 \pm 0 \cdot 2 \mathrm{~kg}$ ) from 15 multiparous Merino-cross ewes without ovary transplantation.

The ovarian secretion rate of progesterone when measured directly was similar at 66 to 103 days p.c. $(5 \cdot 2 \pm 0.9$ (s.e.m.) $\mu \mathrm{g} / \mathrm{min}, 6$ experiments) to the total production rate estimated by tracer kinetics in non-pregnant animals during the luteal phase of the oestrous cycle $(3 \cdot 1 \pm 1 \cdot 3 \mu \mathrm{g} / \mathrm{min}, 4$ experiments: Bedford et al., 1972). The ovarian secretion rates were also similar to those reported by Thorburn \& Mattner (1971) who obtained a value of $5.3 \pm 0.3$ (s.e.m.) $\mu \mathrm{g} / \mathrm{min}$ (22 observations) 
between Days 6 and 10 of the oestrous cycle in sheep in which the utero-ovarian vein was anastomosed to the anterior mammary vein for the collection of utero-ovarian blood.

The total production rate of progesterone increased over the later stages of pregnancy from $12 \mu \mathrm{g} / \mathrm{min}(66-103$ days p.c.) to $26 \mu \mathrm{g} / \mathrm{min}(107-129$ days p.c.) to $31 \mu \mathrm{g} / \mathrm{min}(133-145$ days p.c.) (Table 1). The rate of ovarian secretion declined during this time and the rate of adrenal secretion remained at a low value of $<0.01-0.07 \mu \mathrm{g} / \mathrm{min}$. The difference between the rate of production and the rates of ovarian and adrenal secretion also increased (Table 1).

Table 1. Metabolic clearance rate and production rate of progesterone measured in blood, and ovarian and adrenal secretion rates of progesterone in three sheep during pregnancy

\begin{tabular}{|c|c|c|c|c|c|c|c|}
\hline \multirow[b]{2}{*}{$\begin{array}{l}\text { Stage of } \\
\text { gestation } \\
\text { (days p.c.) }\end{array}$} & \multirow{2}{*}{$\begin{array}{c}\text { Metabolic } \\
\text { clearance } \\
\text { rate } \\
(1 / \mathrm{min})\end{array}$} & \multirow{2}{*}{$\begin{array}{c}\text { Total } \\
\text { production } \\
\text { rate } \\
(\mu \mathrm{g} / \mathrm{min})\end{array}$} & \multicolumn{2}{|c|}{ Ovarian } & \multicolumn{2}{|c|}{ Adrenal } & \multirow[b]{2}{*}{$\underset{(\mu \mathrm{g} / \mathrm{min})}{\Delta \dagger}$} \\
\hline & & & $\begin{array}{l}\text { Blood flow } \\
(\mathrm{m} 1 / \mathrm{min})\end{array}$ & $\begin{array}{l}\text { Secretion } \\
\text { rate } \\
(\mu \mathrm{g} / \mathrm{min})\end{array}$ & $\begin{array}{l}\text { Blood flow } \\
\text { (ml/min) }\end{array}$ & $\begin{array}{c}\text { Secretion } \\
\text { rate } \\
(\mu \mathrm{g} / \mathrm{min})\end{array}$ & \\
\hline $66(\mathrm{~F})$ & 2.93 & $12 \cdot 8$ & 10.7 & 6.9 & 11.4 & 0.04 & 5.9 \\
\hline $72(\mathrm{G})$ & $2 \cdot 72 \ddagger$ & 6.5 & $8 \cdot 7$ & $2 \cdot 0$ & 7.0 & $<0.02$ & $4 \cdot 5$ \\
\hline $90(\mathrm{Fl})$ & 2.25 & $14 \cdot 3$ & $22 \cdot 3$ & $5 \cdot 0$ & $10 \cdot 1$ & $<0.01$ & $9 \cdot 3$ \\
\hline 93 (F) & $3.34 \ddagger$ & 10.0 & $10 \cdot 6$ & 7.0 & 12.0 & 0.05 & 3.0 \\
\hline $93(G)$ & $2 \cdot 72 \ddagger$ & $8 \cdot 4$ & 12.0 & 2.9 & 7.5 & 0.02 & $5 \cdot 5$ \\
\hline $103(F)$ & $3 \cdot 76$ & $20 \cdot 5$ & $11 \cdot 4$ & $7 \cdot 4$ & $7 \cdot 7$ & 0.02 & $13 \cdot 1$ \\
\hline Mean \pm s.e.m. & $2.95 \pm 0.21$ & $12 \cdot 1 \pm 2 \cdot 0$ & $13 \cdot 0 \pm 2.4$ & $5.2 \pm 0.9$ & $9.3 \pm 0.9$ & 0.02 & $6.8 \pm 1.5$ \\
\hline $107(G)$ & $2 \cdot 72 \ddagger$ & $20 \cdot 7$ & $12 \cdot 2$ & $10 \cdot 3$ & 6.5 & $0 \cdot 18$ & $10 \cdot 2$ \\
\hline 114 (F) & $3.83^{\circ}$ & 23.7 & 11.0 & 6.2 & $9 \cdot 0$ & $<0.01$ & $17 \cdot 5$ \\
\hline $121(\mathrm{G})$ & 2.72 & $33 \cdot 7$ & 6.0 & $12 \cdot 4$ & $4 \cdot 7$ & 0.11 & $21 \cdot 2$ \\
\hline $122(F)$ & 3.90 & $15 \cdot 8$ & 8.0 & $2 \cdot 4$ & $13 \cdot 6$ & 0.01 & $13 \cdot 4$ \\
\hline 124 (Fi) & $3 \cdot 12$ & $47 \cdot 1$ & $17 \cdot 1$ & $1 \cdot 1$ & 12.4 & 0.04 & 46.0 \\
\hline 129 (F) & $4 \cdot 33 \ddagger$ & $12 \cdot 8$ & $10 \cdot 0$ & 3.9 & $10 \cdot 5$ & 0.05 & 8.9 \\
\hline Mean \pm s.e.m. & $3.43 \pm 0.28$ & $25 \cdot 6 \pm 5 \cdot 2^{*}$ & $10 \cdot 7 \pm 1.6$ & $6 \cdot 1 \pm 1 \cdot 8$ & $9.5 \pm 1.4$ & 0.07 & $19 \cdot 5 \pm 5 \cdot 6^{* *}$ \\
\hline $133(\mathrm{Fl})$ & $3 \cdot 29 \ddagger$ & $37 \cdot 1$ & 22.5 & 0.2 & 5.9 & $<0.01$ & 36.9 \\
\hline $133(G)$ & $2.99 \ddagger$ & 30.5 & $14 \cdot 0$ & $2 \cdot 7$ & $7 \cdot 3$ & $<0.01$ & $27 \cdot 8$ \\
\hline $138(G)$ & $3 \cdot 25$ & $37 \cdot 5$ & $13 \cdot 0$ & $2 \cdot 8$ & 5.0 & $<0.01$ & $34 \cdot 7$ \\
\hline $139(F)$ & 4.75 & $18 \cdot 5$ & 9.4 & $4 \cdot 6$ & $10 \cdot 3$ & $<0.01$ & 13.9 \\
\hline $145(\mathrm{Fl})$ & $3 \cdot 45$ & 33.0 & $7 \cdot 5$ & $0 \cdot 1$ & 8.0 & $<0.01$ & $32 \cdot 9$ \\
\hline Mean \pm s.e.m. & $3.54 \pm 0.31$ & $31 \cdot 3 \pm 3 \cdot 4^{*}$ & $13 \cdot 2 \pm 2 \cdot 6$ & $2 \cdot 1 \pm 0.9$ & $7.3 \pm 0.9$ & $<0.01$ & $29 \cdot 2 \pm 4 \cdot 1^{* * * *}$ \\
\hline
\end{tabular}

The experiments were classified to provide groups of approximately similar size. $\mathrm{F}=\mathrm{Frances} ; \mathrm{Fl}=\mathrm{Flossie}$; $\mathrm{G}=$ Godiva.

Values which are significantly different from the respective means for the period of $66-103$ days are $* P<0.05$ ${ }^{* *} P<0.01, * * * P<0.001$ (analysis of variance).

$\dagger \Delta=$ Production rate - (ovarian secretion rate + adrenal secretion rate).

$\ddagger$ Average values for the metabolic clearance rate determined immediately before and after the stated time of gestation.

\section{Discussion}

Bedford et al. (1972) obtained a value of $7 \cdot 5 \pm 0.4 \mu \mathrm{g} / \mathrm{min}$ for total progesterone production, determined by tracer kinetics, in sheep during the first 43 days of gestation. This value is higher than that of the normal cycle and since the corpus luteum is the major source of progesterone until about Day 50 post coitum the increased production rate may be due to a luteotrophic effect of gestation or to the onset of placental progesterone secretion. The present observation of an increasing difference between total progesterone production rate and progesterone secretion by the transplanted ovary and adrenal $(\Delta$, Table 1$)$ can be attributed to placental secretion of progesterone. This placental 
secretion exceeded that of the ovary between Days 66 and 103 p.c. and increased approximately 4 -fold in the second half of gestation. These $\Delta$ values for placental progesterone secretion may be too high if the hormone is produced by tissues other than the ovary, adrenal and placenta. However, from other studies (Linzell \& Heap, 1968; Thorburn, Challis \& Robinson, 1977) it seems that these organs constitute the major sources of progesterone secretion in the sheep and a combination of the techniques of autotransplantation and tracer kinetics should therefore be valid for making indirect and repeated measurements of placental steroid secretion in the conscious animal. Our results for placental progesterone secretion at 107 to 129 days p.c. $(19 \cdot 5 \pm 5 \cdot 6 \mu \mathrm{g} / \mathrm{min})$ compare well with a progesterone secretion rate of $10 \mu \mathrm{g} / \mathrm{min}$ measured from one horn of the gravid uterus in an acute experiment, at 125 days p.c., which was carried out under anaesthesia and involved cannulation of the uterine vein and measurement of uterine blood flow by thermodilution (Linzell \& Heap, 1968).

Marked differences were observed between the individual animals in the blood flow through the transplanted ovary and in the duration of ovarian progesterone secretion. In sheep Flossie, ovarian blood flow was high, perhaps because of the difficulty of completely occluding the jugulo-ovarian vein cranial to the transplant where the vessel was not exteriorized in a skin-covered loop. In this animal the rate of ovarian secretion declined after Day 90 p.c. The formation of an active corpus luteum in a subsequent breeding season verified the viability of the transplant (see Harrison, Heap \& Silver, 1974). In sheep Frances and Godiva, the ovarian contribution to progesterone production was sustained for a longer period. This variability between individual animals may explain the findings of Fylling (1970) that ovariectomy in the last third of pregnancy caused a reduction in the plasma progesterone concentration in 2 of 3 animals. However, in our experiments, ovarian progesterone secretion at this stage of gestation was already low and accounted for less than one-tenth of the total production rate.

It may be a coincidence that pregnancy failed in the 2 animals with twin pregnancies, or ovarian ischaemia at operation could have resulted in an impairment of subsequent luteal function. It is certain that the transplanted ovaries of these two sheep (Edwina and Florence) were functionally subnormal because neither showed oestrous behaviour during the two subsequent breeding seasons whereas sheep with singleton pregnancies (Godiva and Flossie) showed the sporadic oestrous behaviour typical after a successful ovary transplant (Goding, Harrison, Heap \& Linzell, 1967). The transplants in Florence and Frances nevertheless secreted progesterone at rates sufficient to produce hydrometra with elevated prostaglandin levels in uterine fluid (Harrison, Heap, Horton \& Poyser, 1972), and a small corpus luteum was seen at post mortem in the transplanted ovary of Edwina.

We thank Miss Grace Needham for skilled technical assistance and for her care of the experimental animals.

\section{References}

Bedford, C.A., Harrison, F.A. \& Heap, R.B. (1972) The metabolic clearance rate and production rate of progesterone and the conversion of progesterone to $20 \alpha$-hydroxypregn-4-en-3-one in the sheep. $J$. Endocr. 55, 105-118.

CASIDA, L.E. \& WARWICK, E.J. (1945) The necessity of the corpus luteum for maintenance of pregnancy in the ewe. $J$. Anim. Sci. 4, 34-36.

Denamur, R. \& Martinet, J. (1955) Effets de l'ovariectomie chez la Brebis pendant la gestation. C. $r$. Séanc. Soc. Biol. 149, 2105-2107.

Fylling, P. (1970) The effect of pregnancy, ovariectomy and parturition on plasma progesterone level in the sheep. Acta endocr., Copenh. 65, 273-283.

Goding, J.R., Harrison, F.A., Heap, R.B. \& Linzell, J.L. (1967) Ovarian activity in the ewe after auto- transplantation of the ovary or uterus to the neck. J. Physiol., Lond. 191, 129P-130P.

Goding, J.R., McCraCken, J.A. \& BAIRD, D.T. (1967) The study of ovarian function in the ewe by means of a vascular autotransplantation technique. J. Endocr. $39,37-52$.

Harrison, F.A. \& Heap, R.B. (1968) Progesterone secretion by the autotransplanted adrenal and ovary in a pregnant sheep. J. Physiol., Lond. 196, 43P-45P.

Harrison, F.A. \& Paterson, J.Y.F. (1965) The specific activity of plasma cortisol in sheep after rapid intravenous injection of $\left[1,2-{ }^{3} \mathrm{H}_{2}\right]$ cortisol, and its relation to the rate of cortisol secretion. $J$. Endocr. 33, 477-490.

Harrison, F.A., Heap, R.B., Horton, E.W. \& Poyser, N.L. (1972) Identification of prostaglandin $F_{2 \alpha}$ in 
uterine fluid from the non-pregnant sheep with an autotransplanted ovary. J. Endocr. 53, 21 5-222.

Harrison, F.A., Heap, R.B. \& Silver, A. (1974) Cholinesterase activity in the autotransplanted ovary of a sheep. J. Physiol., Lond. 242, 10P-11P.

LINZELL, J.L. \& HEAP, R.B. (1968) A comparison of progesterone metabolism in the pregnant sheep and goat: sources of production and an estimation of uptake by some target organs. J. Endocr. 41, 433-438.

MCDONALD, I.R., Goding, J.R. \& WRIGHT, R.D. (1958) Transplantation of the adrenal gland of the sheep to provide access to its blood supply. Aust. $J$. exp. Biol. med. Sci. 36, 83-96.

Thorburn, G.D. \& MATrner, P.E. (1971) Anastomosis of the utero-ovarian and anterior mammary veins for collection of utero-ovarian venous blood: progesterone secretion rates in cyclic ewes. J. Endocr. 50, 307-320.

Thorburn, G.D., Challis, J.R.G. \& Robinson, J.S. (1977) Endocrine control of parturition. In Biology of the Uterus, pp. 653-732. Ed. R.M. Wynn. Plenum Press, New York.

Received 28 January 1978 